\title{
Producing territory: territorial organizing of movements in Buenos Aires
}

\author{
Liz Mason-Deese ${ }^{1}$, Victoria Habermehl ${ }^{2}$, and Nick Clare ${ }^{3}$ \\ ${ }^{1}$ independent researcher \\ ${ }^{2}$ The Urban Institute, University of Sheffield, Sheffield, UK \\ ${ }^{3}$ School of Geography, University of Nottingham, Nottingham, UK \\ Correspondence: Liz Mason-Deese (liz.masondeese@gmail.com)
}

Received: 11 May 2018 - Revised: 2 April 2019 - Accepted: 3 April 2019 - Published: 3 May 2019

\begin{abstract}
In this paper we analyze the territorial organizing of two dissimilar social movements across Greater Buenos Aires, showing how urban struggles produce territory as a key element of their political practice. Through their relational, contested character, these Latin American territories foreground an alternative to state-centric, Anglo-American models of territorial politics. First, the unemployed workers' movements in the urban periphery show how the territorial organization of production and reproduction creates new social relations, and second, an assembly-organized market emphasizes the relationality of territory in constructing solidarity economies. This paper contributes to debates on urban social movements by showing that these movements use practices of territorial organizing to produce urban territory in distinct ways, and that territorial organizing is relational, contested, and central to movements' praxis.
\end{abstract}

\section{Territorial organizing as movement praxis}

In recent decades, some of the most important social movements in Latin America have concentrated on "territorial organizing", highlighting the political importance of territory to urban struggles. Movements of the unemployed and alternative economic networks each center territory in their political praxis and everyday urban organizing. Yet, rather than stake claims to preexisting territories, these movements actively produce their own territories in an attempt to avoid reproducing the territorialities of the state and capital. That is not to say, however, that these territories are completely "outside" the state and market but that they are fundamentally linked to the creation of new forms of social relations and subjectivities while simultaneously being contested and relational (Clare et al., 2018). In this paper we explore the praxis of territorial organizing as developed by social movements in Buenos Aires. Here territorial organizing refers to political work (both theory and practice) that focuses on questions and spaces of everyday life and, by producing new spatialities, creates new social relations and subjectivities. As such, territorial organizing aims to directly create new possibilities without seeking power over others or at a greater scale, based on the idea that power lies in everyday life and social relationships.

Territorial movements rapidly expanded in the context of the devastating effects of neoliberalism that swept Latin America in the 1990s and early 2000s, remaking both urban and rural spaces. In Argentina, protests were directed against a decade of neoliberal policies, which had increased inequality, poverty, and unemployment and left the country in severe economic crisis. This crisis did not only affect $\mathrm{Ar}$ gentina, however, with neoliberalism's disastrous effects felt across the entire region. From the Bolivian water and gas wars, to the Argentinian 2001 rebellion under the banner of "they all must go," neoliberal governments were met with multiple forms of resistance (Colectivo Situaciones, 2012; Gutiérrez Aguilar, 2014; Zibechi, 2008). Yet this resistance did not only occur on a large-scale, visible protests that attacked sites of centralized power but also in the everyday territorial organizing of hundreds of social movements that built power and new spatial relations in neighborhoods where people live, work, and trade.

We argue that approaching struggles through the idea of territorial organizing can be especially useful for understand- 
ing urban conflicts and the productive aspects of social movements. This perspective moves us away from an overfocus on the spectacular moments of protest and alerts us to different forms of power. Concentrating our attention on territorial organizing allows us to better understand movements' potentials and challenges, as well as the processes by which territory itself is produced. Territorial organizing is crucial to the two movements which we focus on in Greater Buenos Aires: an unemployed workers' movement and a solidarity market. We develop a method of dissimilar comparison building on comparative urbanism (Robinson, 2016; Myers, 2014) to explore two different projects of territorial organizing in very different neighborhoods of Greater Buenos Aires. We show how territory is a crucial category for understanding urban movements, demonstrating the importance of non-state actors in producing urban territory. Through following movements' practice, this paper asks: how does this territorial organizing differ from, and enter into conflict with, notions of territory associated with the state and sovereign power?

In this paper (Sect. 2), we explore some of the theoretical understandings of "territory" being developed in Latin America, from which the praxis of territorial organizing is drawn. Next we present our two cases (Sect. 3), analyzing individual moments of territorial organizing from each movement, to explore key practices that constitute territorial organizing. We finish by putting the two cases into dialogue (Sect. 4) to analyze how geography matters to territorial organizing and how communities are able to engage in territorial organizing in different circumstances, despite the many contradictions (in terms of state-based or capitalist social relationships) of everyday life. As such, by looking at different cases we demonstrate how different non-state actors produce territories in contested and relational ways.

\section{Understanding territorial organizing}

Contemporary urban struggles in Latin America have fundamentally challenged the dominance of Anglophone analyses of territory (Del Biaggio, 2015) that typically feature a residual statism (Halvorsen, 2018; Schwarz and Streule, 2016). Instead, they pose a conception of territory that emphasizes the production of territory through struggle, in which social movements and the popular classes play a key role (Stratta and Barrera, 2009). In this framework, territory is not an object that movements seek to defend, but a site of struggle and the product of the struggles themselves (Blank, 2016; Oliveira, 1999; Sitrin, 2012; Stratta and Barrera, 2009). Territory, in this case, is always socioterritorial, intimately tied to the social relations that are enacted in it (Zibechi, 2012), and is immanently traversed by power relations (Clare et al., 2018). Thus, the territoriality of Black and Indigenous communities, as well as other anti-colonial and anticapitalist movements, is different from the territory of nation-states. In one of the most telling examples, Reyes and Kaufman
(2011), examining the Zapatista movement, argue that by occupying their own territories, the Zapatistas are able to produce an autonomous territoriality that, as a rupture emerging in, against, and beyond sovereign forms of territoriality, allows for the creation of new social relations and new forms of government. In other words, multiple territories are possible but these are always relational and contested (Clare et al., 2018). To focus on Latin American territorial analyses is not, therefore, to create a false dichotomy between them and those that are "Eurocentric", nor is it to homogenize bodies of literature. Instead, it furthers productive dialogues (Halvorsen, 2018) that allow more expansive, polymorphic analyses of territory and thus territorial organizing (Blank, 2016).

Territory, as understood by Latin American movements and scholars, is intimately connected to the production of subjectivity and social relations, which is especially clear in rural examples. For example, Zibechi (2008) explores how Indigenous, landless, and campesino movements are territorialized through the production of non-hegemonic social relations and subjectivities. These territories are not based on possession or ownership of the land, which would reproduce a capitalist subjectivity but on their multiple collective uses (Porto Gonçalves, 2001). The struggle for territory privileges difference and multiplicity, as demonstrated by the struggles of Afro-Colombian communities (Escobar, 2008). Similarly, Colombian peace communities have mobile and unbounded notions of territoriality constructed through multiple practices, including food production, memorial actions, and educational activities (Courtheyn, 2017). These movements thus produce territories that are more than state-centric and capitalist; territories that are not static or based on private property, but rather are fluid and relational and grounded in communal use value.

It is from these movements' understandings of territory, therefore, that the idea of territorial organizing emerges, and urban territorial organizing in Latin America (see Blank, 2016) is explicitly connected to, and draws on, lessons from these rural movements (Clare et al., 2018). But urban territorial organizing faces particular challenges: cities are where capital is concentrated, is most densely policed, and, in many cases, their very architecture is a product of colonial power relations. Urban territory is produced through difference as diverse communities and practices inhabit the same space - and is constantly being contested and remade through simultaneous conflicting processes of enclosure and encounter (Picotto and Sadier, 2013). Yet despite the fragmentation and violence that proliferates there, it is precisely in the urban peripheries of major Latin American cities where residents can self-construct their own neighborhoods, privileging use over exchange values (Zibechi, 2008:36). In the face of contestation, urban territorial organizing is fluid and mobile. For instance, community radio stations in Puebla (Navarro, 2016) and Buenos Aires (Gago, 2017) create relational, common territorialities for Indigenous youth and migrants in a frag- 
mented urban landscape, affording often geographically dispersed and isolated individuals a sense of community and solidarity over the airwaves. Indigenous struggles also especially challenge state-based territorialities through their own urban "planning" and resident control in these dispersed settlements (Zibechi, 2010). Thus, it is fundamental to understand the contested nature of urban territorial organizing across Latin America in order to analyze the realities facing social movements, realities often rendered invisible by Anglophone analyses (Halvorsen, 2018).

Building on the movements' own use of the term, we refer to territorial organizing to demonstrate the practices and theories that are developed by movements across Latin America to build a capacity in communities where they are situated (Blank, 2016). This concept focuses on the territorial basis of movements' organizing through which they can transcend their "assigned" societal place to create new territories of resistance (Porto Gonçalves, 2001). Focusing on movements' territorial organizing engages with the everyday and the prefigurative, avoids bracketing "politics" off as optional (Zibechi, 2012), and highlights the importance of autonomous social reproduction (Stavrides, 2016; Sitrin, 2016). Importantly, the concept also avoids a binary representation of bounded versus relational territorial analyses by focusing on contested and everyday territorial practices through which to analyze movements' struggles. Thus, territorial organizing is a form of praxis (Blank, 2016) and it must be understood in terms of contestation (Clare et al., 2018). We use this concept to highlight the messy and important struggles of movements to constitute and build their own power in everyday contestation with capitalist social relations. We now turn to two cases from Buenos Aires, focusing on urban movements that are complex examples of these struggles between enclosure and encounter. These movements of the unemployed and members of an alternative solidarity market each territorially organize despite the challenges and impositions they face from the state and capital, emphasizing the complex and contested nature of territorial organizing, and the need for nuanced understandings of territory with which to approach these.

\section{Research context and methodology: the contested practices of territorial organizing in Buenos Aires through a dissimilar comparison}

Greater Buenos Aires is an urban region with a population of over 13 million people (see Fig. 1). The region is divided between the Autonomous City of Buenos Aires (CABA), with its own government, and the 24 surrounding districts belonging to the Province of Buenos Aires that make up the surrounding conurbano (urban periphery). Those districts range from wealthier suburbs in the north to the more working-class districts concentrated in the west and south. The territoriality of Buenos Aires has long been constructed through conflict, starting with the European conquest and near decimation of the Indigenous populations, and continuing through Peronist grassroots organizing in working class neighborhoods and the brutal repression of urban movements during the last military dictatorship. Starting in the 1980s and the "return to democracy" with a democratically elected government, a new wave of land settlements and territorial organizing has defined the city (Stratta and Barrera, 2009). Migrant settlements in the periphery in the 1980s were particularly important and their struggles not only for rights to land but for services and to improve the quality of life on those lands would be an important reference for later movements (Zibechi, 2008).

The two cases take place in different parts of Greater Buenos Aires, chosen to represent the differentiation of neighborhoods across the area. Our first location is the deindustrialized and impoverished districts of Quilmes and Florencio Varela, to the south of the city and (Fig. 1) historically home to some of the country's largest unemployed workers' movements or MTDs (Movimientos de Trabajadores Desocupados). Second, we look at the gentrified neighborhood of Palermo Viejo in the northeast of CABA, where Mercado Bonpland, a small neighborhood solidarity market, is situated (Fig. 1, green dot). Bringing together these varied cases, through a dissimilar comparison highlights both the achievements and the contradictions of territorial organizing, as well as the difference that geography makes in creating or foreclosing opportunities for the production of territory in urban settings. Their commitment to territorial organizing means that each of these movements recognizes the importance of reading the territory and attempts to enact geographically appropriate strategies. Together these cases demonstrate three substantive points: the creation of new social relations, the relational construction of territory, and contestation over territory.

This paper focuses on research undertaken between 2009 and 2016, when the authors spent substantial periods of time undertaking ethnographic research in the neighborhood of Palermo Viejo and the municipalities of Quilmes and Florencio Varela ${ }^{1}$ This ethnography was longitudinal and involved repeated periods of both traditional participant observation and more involved and engaged observant participation (Wacquant, 2010) to help produce richer and deeper data. This ethnographic approach was also supported by 77 semi-structured interviews with a range of individuals and groups, and these data were then analyzed inductively, exploring similarities and differences across and between researchers (Jackson, 2001).

We focus on this particular time because it was a period of territorial transformation when new conflicts were emerging to highlight and make a dissimilar comparison of the

\footnotetext{
${ }^{1}$ The cases emerged from long periods of fieldwork, based on the particular histories of each case and their embedded territorial organizing. Further research could extend these cases, examining other scales, geographies, and examples of organizing.
} 


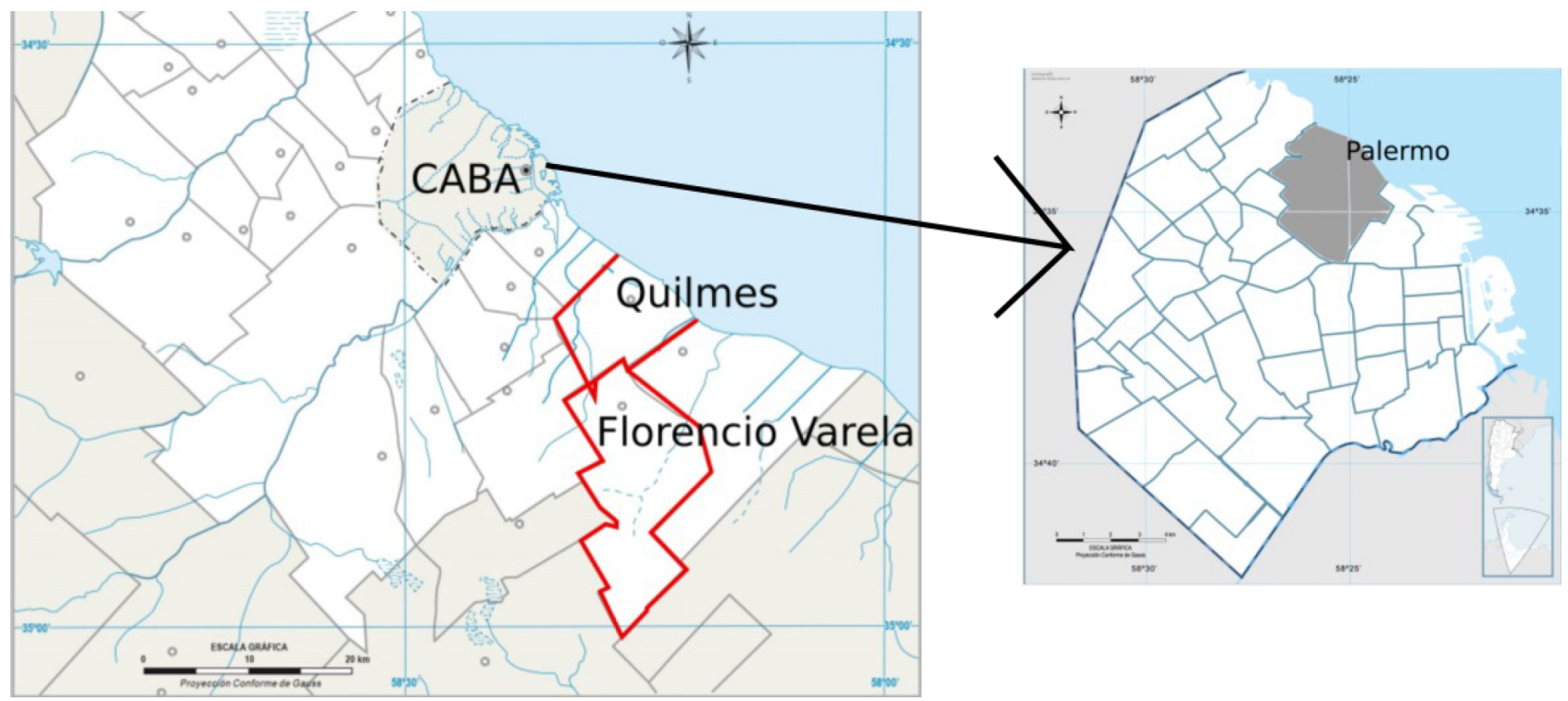

Figure 1. Map to show Greater Buenos Aires and CABA. Source: Instituto Geográfico Nacional, Argentina.

capacity of neighbors to organize territorially. This snapshot allows us to ground these dissimilar territorial organizing strategies in order to bring these cases into discussion with each other, to reveal insights into these strategies and practices. This paper builds its method from urban studies' calls to challenge comparative methods and theory developed through northern "encounter", through "unexpected comparison" (Myers, 2013), "new comparative urbanisms" (Robinson, 2016), and "new vocabulary" (Schmid et al., 2018). This research is drawn directly from deep ethnographic research in variegated and "southern" contexts that draw on postcolonial urban studies research to examine the "ordinary city" (Robinson, 2006). Rather than a focus on synthesis or universality, dissimilar comparison of territorial organization at the neighborhood scale highlights different contexts and practices across the city region to take relational theories of territory seriously. This paper develops this by examining two different neighborhoods (and two varied projects within these) as a starting point to draw out a "dissimilar comparison", in order to establish processes, and important tactics to operationalize territorial organizing. Comparing the differences between neighborhoods in the same urban region highlights the need to be attentive to context when building arguments about practice. This paper uses the dissimilar social groups and geographical location of these neighborhoods to develop insights into territorial organizing. The value of this dissimilar comparison is to use the difference of each neighborhood to highlight the way in which territory is organized, and at the same time using these dissimilarities to continue to draw out what is useful in the process.

\subsection{Production of territory by unemployed workers' movements}

"After participating in several land takeovers in the south of Greater Buenos... we started to think about what would happen when the land was won... Often other types of logics, very different from the ones that we wanted for ourselves were imposed. Thus, need emerged to construct a community space, where the logic of individualism wouldn't reign, where we could project a life together with friends." (Interview, Florencio Varela, September 2012).

The MTD of Solano, founded in 1997, brought together neighborhood residents in one of the most densely populated and poorest areas of Greater Buenos Aires, San Francisco de Solano, to protest unemployment, rising food costs and the lack of state action. This area, which was occupied and settled by grassroots movements supported by the progressive wing of the Catholic Church in the 1980s, still lacked many basic services, such as sewers, paved roads and public transportation. As the crisis hit, it was one of the most affected by the rise of unemployment, with many families facing extreme hunger. After initially occupying a local church, the MTD organized roadblocks to publicize their grievances, and direct action, such as occupying supermarkets to demand food but soon realized that contestation alone was not sufficient. Through processes of collective investigation into problematics of the neighborhood (Mason-Deese, 2017), they began more permanently occupying space to focus on directly meeting peoples' needs related to social reproduction: particularly through land takeovers and occupations, and later through opening a health clinic and community garden. As part of the Aníbal Verón, a coordinating platform of several MTDs, they operated several small cooperative enterprises, 
serving as models for a different type of work: collectively controlled by workers. Other MTDs similarly engaged in territorial organizing to gathering people at the neighborhood scale to collectively meet their needs and enact new forms of social organization (Delamata, 2004; Svampa and Pereyra, 2009).

This territorial organizing provides important insights into the production of territory from below. First, movements emphasize that territorial organizing does not occur over a preconstituted territory; while neighborhoods may exist on the map, often fragmentation and violence preclude any sense of unity or identity. One member of the MTD of Solano described it in the following way: "Here in Buenos Aires the social field is very disintegrated: if you are unemployed and you go out to block a road, your neighbor who has to get to work will run you over. Here people are more fucked up, there is complete individualism" (Colectivo Situaciones and MTD of Solano, 2002:67). Territorial organizing thus starts from the need to produce a territory by building new social relations. This sets it apart from local or place-based organizing that posits preexisting local identities in opposition to a deterritorializing globalization. Instead, territory is actively produced through the interaction of power relations acting at multiple scales. The effects of international financial institutions, national and municipal governments, and transnational and local businesses, all influence daily life in a typical neighborhood of the conurbano. The MTDs themselves actively engaged in building networks and connections with other movements within Argentina, the region, and internationally, for example, participating in World Social Forums or hosting activists from other regions.

Second, MTDs produce territory in accordance with their overall political objectives. Dinerstein (2014:1040) argues that the MTDs create "heterotopic spaces" through everyday activities and affects and that "in the Piqueteros" demarcated territories, alternative forms of sociability, social relations and solidarities, caring practices, learning processes, and emancipatory horizons were fashioned. Delamata (2004:48), looking at the experience of the MTD of Solano, makes a similar argument about the function of territorial organizing:

First, work in the territory is proposed as the production of new values of solidarity that reconstitute interpersonal relations and the existential dimensions of people who have been broken by unemployment, poverty, and the forms of authoritarianism that permeate society in different ways. Second, this communitarian construction aims to produce a new society that does not directly antagonize places of constituted power in order to impose itself but rather projects itself and affirms itself as "non-state sovereignty."

Autonomous practices of social reproduction, constructing different logics, social relations, and subjectivities, as indicated in the opening quote of this section, allow MTDs to control and organize the activities of everyday life that are crucial to this construction of a different territoriality (Mason-Deese, 2017). For example, in the housing cooperative started by former members of the MTD of Solano, they build and arrange houses and other buildings in such a way as to promote more collective ways of life: shared common areas and gardens and ample spaces for meetings and group gatherings. This emphasis arose out of previous experiences with large land takeovers, involving hundreds of families, in different parts of Quilmes and Florencio Varela, in which there was less of a collective focus on remaking the space and the relationship to it. Some of the members involved in these settlements recount how they became sites of real estate speculation or conflicts over property rights between families and neighbors: "the settlement became massive, it was impossible to build relations between everyone, people started selling off their land to make money, the drug dealers came in..." (Interview, Florencio Varela, October 2012). In other words, reproducing the capitalist logic in regard to land. These land settlements, originally collective actions organized by the movement, became fierce battlegrounds between different political parties and their punteros, party representatives who would distribute goods or money in exchange for political support, and later of drug-related violence. Thus, the MTD had to consciously intervene in these dynamics as part of its territorial organizing. That entailed the creation of regular spaces of encounter and assembly between neighborhood residents to discuss common problems and collectively find solutions. These assemblies were the first step toward creating new subjectivities and shared identities, based on the space of the neighborhood from which the movement took its name. Other work groups focused on specific questions, such as health or education, aiming to work collectively to meet shared needs through direct action rather than relying on the state. It is through these practices that the organization produces a territory: both through creating physical institutions and infrastructure and new bonds between neighborhood residents themselves.

This production of territory has never been uncontested, as shown by the increase in distinct forms of violence, from turf wars between drug dealers, police violence to establish state control over neighborhoods, and violence between neighborhood residents over increasingly limited resources (Instituto de Investigación y Experimentación Política, 2014). Recognizing the political and social productivity of these territories, the Kirchner governments enacted their own form of territorial organizing from 2003 to 2015 through new social programs and subsidies targeting low-income populations. These programs employed local activists and used social organizations to distribute benefits, relying on their knowledge of the terrain - the social ecology of the neighborhood and residents' needs and desires - to make the territory of the urban periphery legible to the government (Gago et al., 2014). Capital also entered these territories, through the spread of consumer credit and other forms of finance to low-income 
residents (Gago, 2015; Wilkis, 2015). Right-wing political parties have since adopted territorial organizing as well: inserting themselves into popular neighborhoods, carrying out surveys, and offering residents money and job opportunities (Vommaro, 2016). They focus on issues of insecurity, offering solutions such as more policing, more financial investment, and the privatization and enclosure of public spaces. Thus, competition over the territory of the urban periphery has multiplied in recent years; yet, this contestation only further demonstrates the important potential of the production of territory from below.

\subsection{Challenges of relational territorial organizing in a solidarity market}

Each year, a guy comes with a kilo [of mushrooms] and everything is barter - he takes yerba [mate] and honey because he hasn't any. There are many like him, and what do you tell them? They come here, because they were city residents of Buenos Aires (Interview, Mercado Bonpland, April 2014).

This is how a stallholder describes one of the still existing barter relationships between a producer and the market stall, highlighting two challenges for territorial organizing faced by this solidarity market in a central and gentrified neighborhood of Buenos Aires. First, to organize in the neighborhood to continue the market and alternative economic production, and second the struggle to maintain their presence and organize in this neighborhood, notwithstanding the pressures of gentrification. This barter demonstrates the complex and relational construction of territorial networks of production both in the market through the act of barter and through relational territorial networks. Therefore, to extend and develop the theory of territorial organizing, we explore the relational construction of territorial networks in the solidarity economy. Such an approach is only visible when investigating the multilayered and complex construction of the solidarity economy that this one barter interaction demonstrates.

Mercado Bonpland supports the development of autogestión (movements of self-management) in the neighborhood of Palermo, yet also links producers across the country. Some individuals attend the market to barter produce, a practice which is no longer as visibly present in the city as it once was during the 2001 crisis. At the same time most of the producers in this market are organized through multiple relational territorial connections and autogestive networks initiated during this period. The above quotation describes one moment of barter out of thousands of transactions in Mercado Bonpland and this shows how, over time, organizers created their own networks of territorial production. These production networks are relational in terms of neighborhood and city, and across the country.

Originating from the organizing of the Palermo Viejo neighborhood assembly, Mercado Bonpland focused on cre- ating alternatives to the social, political, and cultural crisis of 2001. A group of the Palermo Viejo assembly began focusing on autogestión, organizing with producers at the many exchange fairs and barter events that took place at this time. By 2007 , the assembly organized to go within Mercado Bonpland, a previously abandoned neighborhood market, in order to sell directly from producers to create a solidarity economy with substantial organizational assistance from various neighborhood associations. The progression of both those involved in the market, running the stalls, and the organization of the market itself is substantive. Each of the 17 stalls represents a cooperative, association, small producer, artisan, recuperated workplace, or network of alternative production. Relations of production are a major focus of the market, as organizers strive for "dignified work" and fair conditions.

A producer's yearly visit to the market to barter, as in the above quotation, is just one case of a common practice. In Mercado Bonpland, people barter either through production networks (before reaching the market), or because they have a historic connection to the market, for example, those who were involved in the assembly during the 2001 period or simply attend the market and buy products. The networks of solidarity economies were built to create sustainable economies in neighborhoods, and Mercado Bonpland remains a place to visit, learn, and meet those who are still organizing.

Yet over time, many residents and producers have been displaced from Palermo and the city, as the stallholder in Mercado Bonpland observes, "they were city residents of Buenos Aires" (Interview, Mercado Bonpland, April 2014). The neighborhood of Palermo has become increasingly expensive and many of the residents that lived, worked, and organized the assembly there have had to leave. One stallholder at the market continues to run her stall to maintain a connection to the neighborhood, which she can no longer afford to live in. Yet the legacies of the Palermo Viejo neighborhood assembly organizing mean that this market continues to represent and organize the neighbors that used to live there, as well as some that still do. Through this barter, we witness producers revisiting and strengthening historic networks which connect Mercado Bonpland with producers. This barter and the continuation of organizing despite displacement, challenge conceptions of local territorial organizing through highlighting the stretching of neighborhood organizing, including displaced neighbors. At the same time, this barter shows the complex organization of producers negotiating the historic political links, the seasons, the crops, and the weather. Numerous producer networks were also initiated by displacement from the city core, necessitating autogestive movements, which still influence the organizing of small producers today. Many of these producers now sell through Mercado Bonpland, for example, several of the small agricultural producers run their own stalls. This case demonstrates the complex and interrelated construction of networks of territorial practices despite gentrification in the neighbor- 
hood and shows how territorial organizing can extend beyond the neighborhood itself.

The 17 organizations within Mercado Bonpland are nodes connecting small producers to the solidarity economy, building on historic networks. But at the same time, they are complex networks of alternative producers that are organized across different territories. La Asamblearia, a stall in Mercado Bonpland, also works with producers to create their own territorial networks, creating nodes in each region from which barter, advice, and collective transport are organized to sell in Mercado Bonpland and similar solidarity markets.

Constituted by networks of social relationships of autogestion emerging from the 2001 crisis (but also before it), interconnected territories are created, sustained, and grown though organizations in Mercado Bonpland. These networks are crucial for the development and continuation of Mercado Bonpland (Habermehl et al., 2018). Thus, the context of the co-facilitation of networks and projects is crucial to developing relational territorial practice. Such networks are organized through hard, everyday work: visiting producers, listening to their needs, helping to solve problems, connecting them with other producers, organizing collaborative logistics, and ensuring that the market sells their products according to their needs. This means that there are no stable supplies of products to the market, as they vary depending on season, production conditions, or producers' choices. Building relational networks of production requires flexibility to adapt to producers' needs and do the hard work of listening to these needs and organizing in each production location, in relation to each other.

Market stallholders must work with networks, from a related position, in order to organize for better production conditions and dignified work. This means being flexible with small producers, from the once a year visit of a mushroom producer, to organizing production networks in regions across Argentina. These networks of social relationships provide economic support through the solidarity economy which facilitate the continuation of many other autogestive projects. Therefore, Mercado Bonpland not only represents the stallholders that organize day-to-day in the market but also the hundreds of other spaces and organizations that provide the goods and services that the market relies on. The market acts as a locus for the alternative autogestive, horizontal practices that grew from 2001, exemplified by the increasing number of occupied workplaces in Argentina (270 in 2012) (Sitrin, 2012:128), which demonstrates the huge network of alternative producers across the country, many of whom are connected to Bonpland. These networks of alternative producers are linked to each other directly through social relationships and histories of organizing together, sharing knowledge and other resources upon which these territorial practices are based.

\section{Conclusions: implications for understanding urban territorial organizing}

Together, these two cases - an MTD and a solidarity market - reveal how communities produce territory in different circumstances and show the relational and contested nature of territorial organizing. They highlight the need to take territorial organizing seriously, to recognize it as a practice that creates other forms of territoriality, without seeking power over others, nor being inattentive to state or city power. Both cases present a different element of territorial organizing: first the MTDs demonstrate the importance of both alternative forms of production and reproduction to create new social relations. Second, the solidarity market shows how organizing alternative economic practices and trade networks produces relational territories that extend beyond the neighborhood. This method of dissimilar comparison between neighborhoods in the same urban region, highlights ethnographic details that are crucial to examining movements practices. Yet further work could extend dissimilar comparative methods beyond these specific cases to examine other scales and territorial organization. Bringing these two projects into dialogue with one another values the production of territory by non-state actors, through recognizing its relational character, in opposition to notions of bounded and fixed territoriality dominant in much of the Anglophone literature. Drawing these dissimilar cases together extends literature on territory by developing three crucial aspects of territorial organizing: the creation of new social relations, the relational construction of territory, and contestation over territory, which we will discuss below.

Both cases reveal that through creating new social relations in particular places movements produce territories. In the urban periphery, organizations of the unemployed operate schools, social centers, cooperatives, and health clinics, in and through which, the unemployed build common identities and nonhierarchical social relations, in contrast to dominant forms of social relations. These were built not from preexisting and predefined neighborhood identities but rather were constructed through the MTDs' own practices, bringing together people from heterogeneous backgrounds and experiences to create shared territorial practices. In Mercado Bonpland, neighbors who have been expelled from the neighborhood continue interacting through historic connections such as networks of producers, beyond Buenos Aires. Thus, relationships of solidarity, and historic ties from neighborhood organizing, construct a territoriality that extends beyond a predefined temporally and geographically enclosed space. In each of these examples, it is through building new social relations that territory is being defined and produced. In other words, the territory does not preexist the practices and social relations that compose it, movements do not struggle to control a particular territory but to construct it according to their own principles and values.

While the forms of territoriality constructed by these movements differ, their relational organizing challenges no- 
tions of bounded and fixed territorialities. The MTDs construct territories from fragmented and competitive social identities in their neighborhoods, not by reifying the neighborhood space but by appealing to shared needs and desires: needs for those basic elements of reproduction and desires to work and live with dignity. Mercado Bonpland functions by bringing together networks not only of trade but of solidarity that expand beyond the neighborhood and city to include many different producers. The scale of these engagements increases support, legitimacy, and social power by enabling collective organizing across different autogestive spaces. Here territorial networks are created through supporting, negotiating, and organizing relationships of producers over the long term. Territorial organizing is comprised of relational practices: identities, spaces, needs, and desires built in long-term engagements.

Finally, these two cases reveal some of the challenges and contradictions that lie within territorial organizing. The MTDs demonstrate how territorial organizing can be captured by the state and capital when they implement their own inverted form of territorial organizing or seek to commodify and profit from the territorial practices and knowledge of movements and neighbors. On the other hand, Mercado Bonpland reveals the tensions that emerge when engaging in territorial organizing in a gentrifying landscape, or the conflicts that arise between multiple ways of valuing urban space: as private property or a common good. There is a temporal aspect to these contestations as well, in which historical struggles over land continue to impact current territorial networks. Thus, rather than the unobstructed construction of noncapitalist territories, territorial organizing must be understood in terms of contestation. What we have shown here is that in this contestation, non-state actors play a powerful role. These non-state actors not only act at the local scale but also operate in multi-scalar terms to produce a territory that is fundamentally relational and that differs from the dominant territoriality of the state. Territorial organizing is situated in processes of struggle, contestation and contradiction.

Being attentive to the theory and practice of movements in Argentina highlights the need for research that examines the contested nature of territorial organizing, as well as those movements' autonomy. Assembling two dissimilar cases of territorial organizing in Buenos Aires in order to explore the ways that movements construct their own territories, this paper contributes to the literature on the study of urban movements contestations around territory. Developed from two dissimilar cases, this comparison advances our understanding into the way in which territorial organizing can shape the urban environment, the granular scale of each case is needed to examine the nuance. While there are variegated contexts, capacities, and outcomes in the two cases, the territorial organizing and subsequent production of territory is crucial to each. Rather than equate each case, however, we have used the divergent examples to highlight the contestations that emerge in each situation. Across the extended ur- ban scale of Buenos Aires, these cases explore the challenges that movements must contend with in the struggle over inclusion and the creation of social relations grounded in solidarity. These movements organize across Greater Buenos Aires and beyond, demonstrating their relational and extended organizing at, and beyond, the urban scale. This multi-scalar and multilayered territorial organizing is complex, yet is undertaken everyday by the movements discussed here. This paper argues that territorial organizing is not only a critical part of movements' praxis but that by examining the way it is produced, makes important contributions to the urban studies debate.

Data availability. The qualitative data collected by the authors (interviews and participant observation) have been deemed confidential due to their sensitive nature by one of the author's internal review boards.

Author contributions. All authors contributed equally to the writing of the paper and the development of the conceptual paper. The research on unemployed workers' movement was carried out by LMD and the research on solidarity economies by VH.

Competing interests. The authors declare that they have no conflict of interest.

Acknowledgements. The authors wish to thank all the organizers, neighbors, and movements with whom we collaborated. Special thanks go to the organizers of the Bonpland Market and all the residents of the comarca, as well as to the editors of this special issue. The authors also acknowledge funding support from the ESRC studentship and Economic and Social Research Council's "Whose Knowledge Matters?" (grant number: ES/N018818/1).

Review statement. This paper was edited by Myriam HoussayHolzschuch and reviewed by two anonymous referees.

\section{References}

Blank, M.: De-fetishizing the analysis of spatial movement strategies: Polymorphy and trabajo territorial in Argentina, Political Geography, 50, 1-9, 2016.

Clare, N., Habermehl, V., and Mason-Deese, L.: Territories in contestation: relational power in Latin America, Territory, Politics, Governance, 6, 302-321, 2018.

Colectivo Situaciones: 19 \& 20: Notes for a New Social Protagonism, translated by: Holdren, N. and Touza, S., Minor Compositions, New York, 2012.

Colectivo Situaciones and MTD de Solano: La Hipótesis 891: Más allá de los piquetes, Ediciones de Mano en Mano, Buenos Aires, 2002. 
Courtheyn, C.: Territories of Peace: Alter-Territorialities in Colombia's San José de Apartadó Peace Community, J. Peasant Stud., 0, 1-28, 2017.

Delamata, G.: Los barrios desbordados. Las organizaciones de desocupados del Gran Buenos Aires, Eudba, Buenos Aires, 2004.

Del Biaggio, C.: Territory beyond the Anglophone Tradition, in: The Wiley Blackwell Companion to Political Geography, edited by: Agnew, J., Mamadouh, V., Secor, A. J., and Sharp, J. P., Wiley, Chichester, UK, 35-47, 2015.

Dinerstein, A. C.: The Dream of Dignified Work. On Good and Bad Utopias, Dev. Change, 45, 1037-1058, 2014.

Escobar, A.: Territories of Difference: Place, Movements, Life, Redes, Duke University Press, Durham, NC, 2008.

Gago, V.: Financialization of Popular Life and the Extractive Operations of Capital: A Perspective from Argentina, translated by: Mason-Deese, L., S. Atl. Q., 114, 11-28, 2015.

Gago, V.: Neoliberalism from Below: Popular Pragmatics and Baroque Economies, translated by: Mason-Deese, L., Duke University Press, Durham, NC, 2017.

Gago, V., Mezzadra, S., Scolnik, S., and Sztulwark, D.: Hay Una Nueva Forma-Estado?, Apuntes Latinoamericanos, Utopía Y Praxis Latinoamericana: Revista Internacional de Filosofía Iberoamericana y Teoría Social, 19, 177-184, 2014.

Gutiérrez Aguilar, R.: Rhythms of the Pachakuti: Indigenous Uprising and State Power in Bolivia, translated by: Skar, S. A., Duke University Press, Durham, NC, 2014.

Habermehl, V., Araya, N., and Arqueros, M.: Mercado Bonpland and Solidarity Production networks in Buenos Aires, Argentina, in Contested Markets, Contested Cities: Gentrification and Urban Justice in Retails Spaces, Routledge, Oxford, 2018.

Halvorsen, S.: Decolonising territory, Prog. Hum. Geog., online first, 1-20, https://doi.org/10.1177/0309132518777623, 2018.

Instituto de Investigación y Experimentación Política: Comprensión Estratégica: Pistas Para La Investigación Política En El Nuevo Conflicto Social, Tinta Limón, Buenos Aires, 2014.

Jackson, P.: Making sense of qualitative data, in: Qualitative Methodologies for Geographers, edited by: Limb, M. and Dwyer, M., Arnold, London, 199-214, 2001.

Mason-Deese, L.: Unemployed Workers' Movements and the Territory of Social Reproduction, Journal of Resistance Studies, 2, 65-99, 2017.

Myers, G.: From expected to unexpected comparisons: Changing the flows of ideas about cities in a postcolonial urban world, Singapore journal of tropical Special Issue: Advancing Postcolonial Geographies, 35, 104-118, 2014.

Navarro, M.: Hacer común contra la fragmentación en la ciudad. Experiencias de autonomía urbana, PhD thesis, Instituto de Ciencias Sociales y Humanidades, Benemérita Universidad Autónoma de Puebla, Mexico, 176 pp., 2016.

Oliveira, A.: A geografia agrária e as transformações territoriais recentes no campo brasileiro, in: Novos caminhos da Geografia, edited by: Carlos, A. F. A., Contexto, São Paulo, 1999.

Picotto, D. and Sadier, E.: Indicios Sobre La Ciudad de Buenos Aires, Lobo Suelto!, available at: http://anarquiacoronada.blogspot.com.ar/2013/05/

indicios-sobre-la-ciudad-de-buenos-aires_6.html (last access: 13 December 2018), 2013.
Porto Gonçalves, C. W.: Geo-Grafías: Movimientos Sociales, Nuevas Territorialidades y Sustentabilidad, Siglo Veintiuno, Mexico City, 2001.

Reyes, A. and Kaufman, M.: Sovereignty, Indigeneity, Territory: Zapatista Autonomy and the New Practices of Decolonization, S. Atl. Q., 110, 505-525, 2011.

Robinson, J.: Ordinary cites. Between modernity and development, Routledge, Oxford, 2006.

Robinson, J.: Comparative Urbanism: New Geographies and Cultures of Theorizing the Urban, Int. J. Urban Regional, 40, 187199, 2016.

Schmid, C., Karaman, O., Hanakata, N., Kallenberger, P., Kockelkorn, A., Sawyer, L., Struele, M., and Wong, K. P.: Towards a new vocabulary of urbanisation processes: A comparative approach, Urban Stud., 55, 19-52, 2018.

Schwarz, A. and Streule, M.: A Transposition of Territory: Decolonized Perspectives in Current Urban Research, Int. J. Urban Regional., 40, 1000-1016, 2016.

Sitrin, M.: Everyday Revolutions: Horizontalism and Autonomy in Argentina, Zed Books, London, 2012.

Sitrin, M.: Rethinking Social Movements with Societies in Movement, in: Social Sciences for an Other Politics: Women Theorizing without Parachutes, edited by: Dinerstein, C., Palgrave Macmillan, Cham, Switzerland, 135-150, 2016.

Stavrides, S.: Common Space: The City as Commons, Zed Books, London, 2016.

Stratta, F. and Barrera, M.: El tizón encendido: protesta social, conflicto y territorio en la Argentina de la posdictadura, El Colectivo, Buenos Aires, 2009.

Svampa, M. and Pereyra, S.: Entre la ruta y el barrio: la experiencia de las organizaciones piqueteras, Editorial Biblos, Buenos Aires, 2009.

Vommaro, G.: Pro-mediadores de lo sensible, Revista Crisis, available at: http://www.revistacrisis.com.ar/notas/ pro-mediadores-de-lo-sensible (last access: 13 December 2018), 2016.

Wacquant, L.: Participant Observation/Observant Participation, 3rd edn., in: Sociology: Introductory readings, edited by: Giddens, A. and Sutton, P. W., Polity Press, Cambridge, 69-73, 2010.

Wilkis, A.: The Moral Performativity of Credit and Debt in the Slums of Buenos Aires, Cultural Stud., 29, 760-780, 2015.

Zibechi, R.: Territorios en resistencia: cartografía política de las periferias urbanas latinoamericanas, Lavaca Editora, Buenos Aires, 2008.

Zibechi, R.: Dispersing Power: Social Movements as Anti-State Forces, translated by: Ryan, R., AK Press, Oakland, CA, 2010.

Zibechi, R.: Territories in Resistance A Cartography of Latin American Social Movements, translated by: Ryan, R., AK Press, Oakland, CA, 2012. 